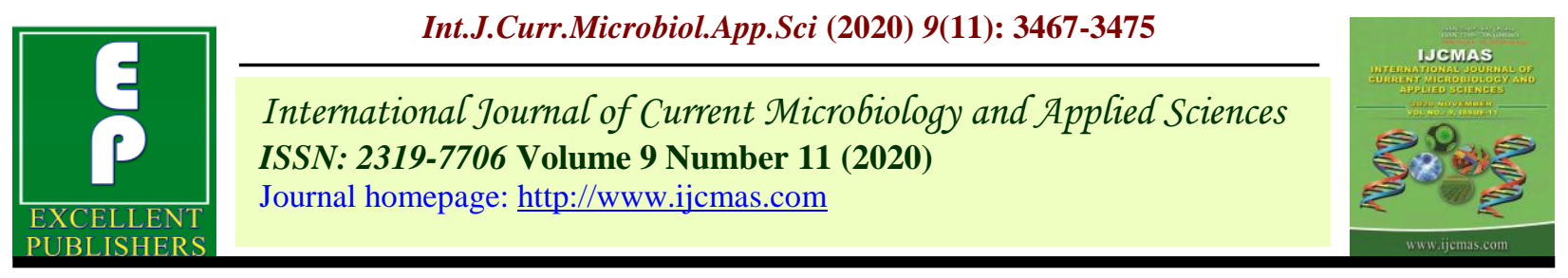

Original Research Article

https://doi.org/10.20546/ijcmas.2020.911.413

\title{
Effect of Pruning Regimes and Fertilizer Levels on Growth, Flowering and Yield of Guava (Psidium guajava L.)
}

\author{
S. B. Shinde*, B. M. Kalalbandi, P. A. Kate and J. M. Shriram \\ Department of Horticulture, College of Agriculture, Latur, Vasantrao Naik Marathwada \\ Krishi Vidhyapeeth Parbhani, India \\ *Corresponding author
}

\section{A B S T R A C T}

Keywords

Pruning, Fertilizer levels, Growth, Flowering, Yield

Article Info

Accepted:

24 October 2020

Available Online:

10 November 2020
The results of the present investigation indicated that, different pruning treatments and fertilizer levels produced significant effect on growth and yield attributes of guava. The treatment of $45 \mathrm{~cm}$ of past season's growth with application of fertilizer levels of 125\% RDF (1000:500:500 g $\mathrm{NPK} /$ tree) recorded the significant effect on the growth parameter like plant height, shoot length, shoot diameter and number of leaves per shoot and produced maximum values of all these growth parameters with minimum days of flowering and fruit set. The maximum yield $(60.41 \mathrm{~kg} /$ tree and $16.79 \mathrm{t} / \mathrm{ha}$.) was recorded in the said treatment.

\section{Introduction}

Guava bears on current season's growth and flowers appears in the axils of new leaves, therefore, it responds well to pruning. Pruning levels under high density planting is vital for building strong frame work of the trees in early years and for maintain vigor, yield, productivity and quality of fruits in later years (Rupankar et al., 2015). A light pruning is considered necessary to encourage new shoots after the harvest. Pruning is helpful in reducing the tree size and improving the fruit quality and provides opportunity to increase the number of tree per unit area and subsequently the higher yield (Kumar and
Rattanpal, 2010). In guava, the flowers and fruits are borne on current season's growth a light pruning is considered necessary to encourage new shoots after harvest. Though guava being an evergreen fruit plant practically no attention has been paid towards its pruning. The technology also helps in maintaining the manageable tree height with open architecture and canopy shoots with outwardly growth facilitating and utilization of light. Yield and quality of guava fruits is significantly influenced due to adoption of improved pruning technology and use of inorganic fertilizers. The vegetative and reproductive growth pattern in guava is promoted with the help of judicious pruning 
and fertilizer application. Optimum pruning and balanced fertilizer application are helpful for increasing the yield and quality production in guava.

\section{Materials and Methods}

The experiment was conducted in a well established orchard of fifteen years age Sardar guava trees planted at $6.0 \times 6.0 \mathrm{~m}$ spacing in FRBD design. The experiment was conducted at Research Farm, college of Agriculture, Latur during Mrigbahar 2019 on trees having uniform growth and vigor. All the cultural and horticultural practices were followed as per the recommendation. The experimental trees were pruned as per treatments in the $2^{\text {nd }}$ fortnight of May and fertilizer doses as per treatments were applied just before the onset of monsoon along with $20 \mathrm{~kg}$ FYM per tree in which half dose of $\mathrm{N}$ and full dose of $\mathrm{P}_{2} \mathrm{O}_{5}$ and $\mathrm{K}_{2} \mathrm{O}$ was applied as basal dose and remaining half dose of $\mathrm{N}$ as per treatments was applied at fruit set stage.

The treatment consisting of two Factor $\mathrm{I}_{-} \mathrm{P}_{0}-$ No Pruning, $\mathrm{P}_{1}-15 \mathrm{~cm}$ of pruning of past season's growth, $\mathrm{P}_{2}-30 \mathrm{~cm}$ of Pruning of past season's growth, $\mathrm{P}_{3}-45 \mathrm{~cm}$ of pruning of past season's growth. Factor II $-\mathrm{F}_{1}-75 \%$ RDF (600:300:300 g NPK/tree), $F_{2}-100 \%$ RDF (800:400:400 NPK/tree), $F_{3}-125 \%$ RDF (1000:500:500 g NPK/tree). In all twelve treatment combinations $\mathrm{P}_{0} \mathrm{~F}_{1}-\mathrm{No}$ pruning $+75 \%$ RDF, $\mathrm{P}_{1} \mathrm{~F}_{1}-15 \mathrm{~cm}$ pruning + $75 \% \mathrm{RDF}, \mathrm{P}_{2} \mathrm{~F}_{1}-30 \mathrm{~cm}$ pruning $+75 \% \mathrm{RDF}$, $\mathrm{P}_{3} \mathrm{~F}_{1}-45 \mathrm{~cm}$ pruning $+125 \% \mathrm{RDF}, \mathrm{P}_{0} \mathrm{~F}_{2}-\mathrm{No}$ pruning $+100 \%$ RDF, $\mathrm{P}_{1} \mathrm{~F}_{2}-15 \mathrm{~cm}$ pruning $+100 \%$ RDF, $\mathrm{P}_{2} \mathrm{~F}_{2}-30 \mathrm{~cm}$ pruning $+100 \%$ $\mathrm{RDF}, \mathrm{P}_{3} \mathrm{~F}_{2}-45 \mathrm{~cm}$ pruning $+100 \% \mathrm{RDF}$, $\mathrm{P}_{0} \mathrm{~F}_{3}-$ No pruning $+125 \%$ RDF, $\mathrm{P}_{1} \mathrm{~F}_{3}-15$ $\mathrm{cm}$ pruning $+125 \% \mathrm{RDF}, \mathrm{P}_{2} \mathrm{~F}_{3}-30 \mathrm{~cm}$ pruning $+125 \%$ RDF, $\mathrm{P}_{3} \mathrm{~F}_{3}-45 \mathrm{~cm}$ pruning $+125 \%$ RDF. The observation calculated once subjected for statistical analysis.

\section{Results and Discussion}

From table 1, it is clear that vegetative growth parameters of guava tree were influenced significantly with different pruning and fertilizer levels. The maximum increase in plant height $(0.74 \mathrm{~m})$, shoot length $(8.44 \mathrm{~cm})$, shoot diameter $(1.37 \mathrm{~mm})$, number of leaves per shoot (6.95) was recorded in $45 \mathrm{~cm}\left(\mathrm{P}_{3}\right)$ pruning level. The minimum values for these parameters were observed in no pruning $\left(\mathrm{P}_{0}\right)$. Regarding the fertilizer levels vegetative growth parameters were also significantly increased with increase in fertilizer doses. Maximum increase in plant height $(0.79 \mathrm{~m})$, shoot length $(9.19 \mathrm{~cm})$, shoot diameter $(1.48$ $\mathrm{mm})$, number of leaves (7.71) was observed with the application of $125 \%$ RDF (1000:500:500 g NPK/tree) $\left(\mathrm{F}_{3}\right)$. The minimum values were recorded in $75 \% \mathrm{RDF}$ (600:300:300 g NPK/tree) $\left(F_{1}\right)$. The interaction effect of pruning and fertilizer levels was also significant on vegetative growth parameters. The maximum increase in plant height $(0.96 \mathrm{~m})$, shoot length $(10.07 \mathrm{~cm})$, shoot diameter $(1.56 \mathrm{~mm})$, number of leaves per shoot (8.52) was recorded in $45 \mathrm{~cm}$ pruning level with application of $125 \% \mathrm{RDF}$ (1000:500:500 g NPK/tree) $\left(\mathrm{P}_{3} \mathrm{~F}_{3}\right)$ treatment. The minimum values for growth parameters were observed in no pruning with $75 \% \mathrm{RDF}$ (600:300:300 g NPK/tree) $\left(\mathrm{P}_{0} \mathrm{~F}_{1}\right)$ application. While, pruning and fertilizer levels showed non-significant effect on stem diameter.

The treatment of $45 \mathrm{~cm}$ pruning and application of 125\% RDF (1000:500:500 g $\mathrm{NPK} /$ tree) produced maximum increase in growth attributes viz. height, shoot length, shoot diameter and number of leaves per shoot. This could be due to as pruning increases the vegetative growth, and may be probably due to an optimization of light environment inside the tree likely to promote photosynthesis rate (Bhuva et al., 2018) in pomegranate. Increase in severity of pruning 
increases shoot length (Lian et al., 2019) in guava trees. Length of new shoots in case of all pruning intensities were found to be significantly greater than those without pruning and also new shoots of guava was found to be highest in severely pruned shoots. This may attributed to relatively less numbers of shoots and availability of more nutrients per shoots under identical condition (Rupankar et al., 2015) in guava. Pruning removes carbon-starved, fruiting exhausted shoots and promotes new leaf growth to build up carbohydrates reserves for the next flowering and allows the sprouting of lateral buds, which ultimately influence the tree height, shoot length, shoot diameter, and other vegetative growth characters of tree this is accordance with the findings of (Kumar and Rattanpal, 2010) in guava.

The maximum diameter of shoot could be attributed to vigorous growth of the shoot, it might have resulted to increased biosynthesis of gibberellic acid with increase in pruning intensity (Sawant et al., 2018) in guava. As regarding to the fertilizers maximum increase in growth parameters with the application of higher level of NPK may be due to more availability of nutrients required for vegetative growth of the trees, and as nitrogen is the major constituent of proteins with is essential for formation of protoplasm thus, affecting the cell division and cell elongation there by maximum increase in vegetative growth parameter of guava trees at higher level of NPK. There is linear increase of growth parameters with the level of NPK. The higher level of NPK resulted in production of maximum growth. Similar results are also reported by (Harrt 1969), who reported that, the increased growth in guava trees may be due to acceleration of the movement of assimilates and increase in translocation of photosynthates as a result of application of NPK in the required quantity.
Data presented in table 2 clearly indicated that, the reproductive parameters of guava trees were influenced significantly with different pruning levels. Minimum days required for flowering (29.73), days required from flowering to fruit set (23.61), days required from fruit set to maturity (148.42) and maximum fruit set $(70.22 \%)$ and fruit retention $(74.36 \%)$ was recorded in $45 \mathrm{~cm}$ pruning level $\left(\mathrm{P}_{3}\right)$. While, minimum values were recorded in no pruning $\left(\mathrm{P}_{0}\right)$ treatment. The results of present study clearly indicated that, pruning of guava trees in various intensity levels responded in positive effect under different fertilizer levels. Pruned trees of $45 \mathrm{~cm}$ level started new vegetative growth immediately after pruning and almost the entire amount of carbohydrates, which otherwise would form flower buds, might have been utilized in the vegetative growth of trees resulting in start of flowering (Adhikari and Kandel, 2015) in guava. Pruning helps in the induction of flowers (Bhuva et al., 2018) in pomegranate. Highest number of flowering intensity was registered with more severity of pruning trees (Chaudhary and Dhakare, 2018) in custard apple. Maximum fruit set (\%) was found in the increasing in severity of pruning intensity (Dahapute et al., 2018) in custard apple. The application of fertilizer dose $125 \%$ RDF (1000:500:500 g NPK/tree) $\left(\mathrm{F}_{3}\right)$ showed best results for minimum days required for flowering (28.69), days required from flowering to fruit set (20.53), days required from fruit set to maturity (147.48) and maximum values for fruit set $(76.92 \%)$, and fruit retention $(83.02 \%)$. The minimum values were recorded in the application of $75 \% \mathrm{RDF}$ (600:300:300 g NPK/tree $) \quad\left(F_{1}\right)$. The application of fertilizer more than that of recommended dose i.e. application of $125 \%$ RDF (1000:500:500 g NPK/tree) has significant effect on reproductive parameters like fruit set $(\%)$, fruit retention $(\%)$ and days required for flowering, fruit set and maturity of guava fruits. Fertilizer doses are known to 
stimulate the rate of biosynthesis of hormones which established the endogenous balance between promoters and inhibitors in favor of fruit promoting process. The minimum days required for flowering, higher flowering and fruit set with higher fruit retention might be due to increased nutrient availability from higher NPK dose might have increased various endogenous hormonal levels in plant tissue which might be responsible for enhancing flowering pollen germination and pollen tube which might have ultimately increased fruit set and higher fruit retention. The results of present findings are confirmed to findings earlier workers (Shukla et al., 2009) in guava. Increase in levels of Nitrogen, Phosphorous and Potassium also plays an important role in increase in fruit set and fruit retention $(\%)$.

Table.1 Effect of pruning regimes and fertilizer levels on growth parameters of guava

\begin{tabular}{|c|c|c|c|c|c|}
\hline Pruning Level & $\begin{array}{c}\text { Plant } \\
\text { Height } \\
\text { (m) }\end{array}$ & $\begin{array}{l}\text { Shoot } \\
\text { Length } \\
\text { (cm) }\end{array}$ & $\begin{array}{c}\text { Shoot } \\
\text { diameter } \\
(\mathbf{m m})\end{array}$ & $\begin{array}{l}\text { No. of } \\
\text { Leaves }\end{array}$ & $\begin{array}{c}\text { Stem } \\
\text { Diameter } \\
(\mathbf{m m})\end{array}$ \\
\hline $\mathbf{P}_{0}$ & 0.38 & 6.52 & 1.01 & 6.28 & 2.37 \\
\hline $\mathbf{P}_{1}$ & 0.47 & 7.73 & 1.04 & 6.51 & 2.55 \\
\hline $\mathbf{P}_{2}$ & 0.61 & 7.83 & 1.07 & 6.52 & 3.27 \\
\hline $\mathbf{P}_{3}$ & 0.74 & 8.44 & 1.37 & 6.95 & 3.44 \\
\hline S.E. & 0.03 & 0.61 & 0.04 & 0.22 & 0.36 \\
\hline C.D. at $5 \%$ & 0.10 & 1.81 & 0.11 & 0.65 & N.S. \\
\hline \multicolumn{6}{|l|}{ Fertilizer level } \\
\hline $\mathbf{F}_{1}$ & 0.35 & 5.97 & 0.81 & 5.63 & 2.58 \\
\hline $\mathbf{F}_{2}$ & 0.51 & 7.72 & 1.08 & 6.38 & 2.86 \\
\hline $\mathbf{F}_{3}$ & 0.79 & 9.19 & 1.48 & 7.71 & 3.27 \\
\hline S.E. & 0.03 & 0.53 & 0.03 & 0.19 & 0.31 \\
\hline C.D. at 5\% & 0.09 & 1.57 & 0.10 & 0.56 & N.S. \\
\hline \multicolumn{6}{|l|}{ Interaction } \\
\hline $\mathbf{P}_{0} \mathbf{F}_{1}$ & 0.25 & 3.36 & 0.49 & 5.26 & 2.56 \\
\hline $\mathbf{P}_{0} \mathbf{F}_{2}$ & 0.30 & 7.38 & 1.22 & 6.28 & 2.08 \\
\hline $\mathbf{P}_{0} \mathbf{F}_{3}$ & 0.61 & 8.83 & 1.31 & 7.30 & 2.46 \\
\hline $\mathbf{P}_{1} \mathbf{F}_{1}$ & 0.29 & 6.81 & 0.60 & 5.70 & 2.04 \\
\hline $\mathbf{P}_{1} \mathbf{F}_{2}$ & 0.40 & 7.55 & 1.07 & 6.33 & 2.59 \\
\hline $\mathbf{P}_{1} \mathbf{F}_{3}$ & 0.75 & 8.85 & 1.57 & 7.50 & 3.01 \\
\hline $\mathbf{P}_{2} \mathbf{F}_{1}$ & 0.38 & 6.82 & 0.66 & 5.72 & 2.62 \\
\hline $\mathbf{P}_{2} \mathbf{F}_{2}$ & 0.60 & 7.60 & 1.01 & 6.43 & 2.84 \\
\hline $\mathbf{P}_{2} \mathbf{F}_{3}$ & 0.85 & 9.03 & 1.53 & 7.53 & 4.35 \\
\hline $\mathbf{P}_{3} \mathbf{F}_{1}$ & 0.50 & 6.89 & 1.47 & 5.87 & 3.12 \\
\hline $\mathbf{P}_{3} \mathbf{F}_{2}$ & 0.77 & 8.36 & 1.09 & 6.47 & 3.93 \\
\hline $\mathbf{P}_{\mathbf{3}} \mathbf{F}_{\mathbf{3}}$ & 0.96 & 10.07 & 1.56 & 8.52 & 3.27 \\
\hline S.E. & 0.05 & 1.07 & 0.07 & 0.38 & 0.63 \\
\hline C.D. at 5\% & 0.15 & 3.19 & 0.21 & 1.13 & N.S. \\
\hline
\end{tabular}


Table.2 Effect of pruning regimes and fertilizer levels on flowering parameters of guava

\begin{tabular}{|c|c|c|c|c|c|}
\hline $\begin{array}{c}\text { Pruning } \\
\text { Level }\end{array}$ & $\begin{array}{c}\text { Days } \\
\text { required } \\
\text { for } \\
\text { Flowering }\end{array}$ & $\begin{array}{c}\text { Days } \\
\text { required } \\
\text { from } \\
\text { flowering to } \\
\text { fruit set }\end{array}$ & $\begin{array}{l}\text { Days required } \\
\text { from fruit set } \\
\text { to maturity }\end{array}$ & $\begin{array}{c}\text { Fruit set } \\
(\%)\end{array}$ & $\begin{array}{c}\text { Fruit } \\
\text { Retention } \\
(\%)\end{array}$ \\
\hline $\mathbf{P}_{\mathbf{0}}$ & 31.99 & 28.53 & 151.62 & 66.00 & 67.93 \\
\hline $\mathbf{P}_{1}$ & 31.41 & 27.11 & 150.33 & 67.00 & 71.24 \\
\hline $\mathbf{P}_{2}$ & 30.90 & 25.78 & 149.80 & 68.33 & 71.95 \\
\hline $\mathbf{P}_{3}$ & 29.73 & 23.61 & 148.42 & 70.22 & 74.36 \\
\hline S.E. & 0.36 & 0.77 & 0.66 & 1.90 & 3.45 \\
\hline C.D. at $5 \%$ & 1.07 & 2.28 & 1.93 & 5.57 & 10.13 \\
\hline \multicolumn{6}{|l|}{$\begin{array}{c}\text { Fertilizer } \\
\text { level }\end{array}$} \\
\hline $\mathbf{F}_{1}$ & 33.08 & 31.30 & 152.86 & 61.50 & 62.51 \\
\hline $\mathbf{F}_{2}$ & 31.05 & 26.94 & 149.80 & 65.25 & 68.59 \\
\hline $\mathbf{F}_{3}$ & 28.89 & 20.53 & 147.48 & 76.92 & 83.02 \\
\hline S.E. & 0.31 & 0.67 & 0.57 & 1.64 & 2.99 \\
\hline C.D. at $5 \%$ & 0.93 & 1.97 & 1.64 & 4.82 & 8.77 \\
\hline \multicolumn{6}{|l|}{ Interaction } \\
\hline $\mathbf{P}_{0} \mathbf{F}_{1}$ & 34.37 & 32.90 & 155.73 & 60.67 & 61.60 \\
\hline$P_{0} F_{2}$ & 31.47 & 28.77 & 150.23 & 63.67 & 61.69 \\
\hline $\mathbf{P}_{0} \mathbf{F}_{3}$ & 30.13 & 23.93 & 148.90 & 73.67 & 75.70 \\
\hline $\mathbf{P}_{1} \mathbf{F}_{1}$ & 33.03 & 31.40 & 153.00 & 60.67 & 61.67 \\
\hline $\mathbf{P}_{1} \mathbf{F}_{2}$ & 31.40 & 27.53 & 149.83 & 64.80 & 67.76 \\
\hline $\mathbf{P}_{1} \mathbf{F}_{3}$ & 29.80 & 22.40 & 148.17 & 76.33 & 84.50 \\
\hline $\mathbf{P}_{2} \mathbf{F}_{1}$ & 32.23 & 30.87 & 151.97 & 62.33 & 63.04 \\
\hline $\mathbf{P}_{2} \mathbf{F}_{2}$ & 31.67 & 26.97 & 149.83 & 65.33 & 67.98 \\
\hline $\mathbf{P}_{2} \mathbf{F}_{3}$ & 29.40 & 19.50 & 147.63 & 77.33 & 85.69 \\
\hline $\mathbf{P}_{3} \mathbf{F}_{1}$ & 32.20 & 30.03 & 150.73 & 62.33 & 63.71 \\
\hline $\mathbf{P}_{3} \mathbf{F}_{2}$ & 30.27 & 24.50 & 149.37 & 68.00 & 73.32 \\
\hline $\mathbf{P}_{3} \mathbf{F}_{3}$ & 26.23 & 16.30 & 147.48 & 80.33 & 87.05 \\
\hline S.E. & 0.63 & 1.35 & 1.14 & 3.29 & 5.98 \\
\hline C.D. at $5 \%$ & 1.86 & 3.95 & 3.35 & 9.65 & N.S. \\
\hline
\end{tabular}


Table.3 Effect of pruning regimes and fertilizer levels on yield parameters of guava

\begin{tabular}{|c|c|c|c|c|}
\hline Pruning Level & No. of Fruits & $\begin{array}{l}\text { Weight of } \\
\text { Fruits (g) }\end{array}$ & Yield (Kg/tree) & Yield (t/ha.) \\
\hline $\mathbf{P}_{0}$ & 352.56 & 139.29 & 49.66 & 13.81 \\
\hline $\mathbf{P}_{1}$ & 362.89 & 141.70 & 51.22 & 14.38 \\
\hline $\mathbf{P}_{2}$ & 373.89 & 145.24 & 54.64 & 15.19 \\
\hline $\mathbf{P}_{3}$ & 389.00 & 153.73 & 60.41 & 16.79 \\
\hline S.E. & 2.82 & 3.91 & 1.64 & 0.45 \\
\hline C.D. at 5\% & 8.29 & 11.73 & 4.82 & 1.34 \\
\hline \multicolumn{5}{|l|}{ Fertilizer level } \\
\hline $\mathbf{F}_{1}$ & 329.5 & 130.83 & 43.17 & 12.00 \\
\hline $\mathbf{F}_{2}$ & 374.50 & 149.36 & 52.97 & 14.73 \\
\hline $\mathbf{F}_{3}$ & 404.75 & 163.16 & 66.19 & 18.40 \\
\hline S.E. & 2.45 & 3.39 & 1.42 & 0.39 \\
\hline C.D. at $5 \%$ & 7.18 & 10.17 & 4.17 & 1.16 \\
\hline \multicolumn{5}{|l|}{ Interaction } \\
\hline $\mathbf{P}_{0} \mathbf{F}_{1}$ & 306.33 & 126.77 & 38.85 & 10.80 \\
\hline $\mathbf{P}_{0} \mathbf{F}_{2}$ & 363.33 & 138.77 & 50.24 & 13.97 \\
\hline$P_{0} F_{3}$ & 388.00 & 154.35 & 59.80 & 16.65 \\
\hline$P_{1} F_{1}$ & 324.00 & 128.73 & 41.70 & 11.59 \\
\hline $\mathbf{P}_{1} \mathbf{F}_{2}$ & 374.00 & 140.20 & 52.43 & 14.58 \\
\hline $\mathbf{P}_{1} \mathbf{F}_{3}$ & 390.67 & 156.17 & 61.03 & 16.97 \\
\hline $\mathbf{P}_{2} \mathbf{F}_{1}$ & 331.33 & 132.47 & 43.87 & 12.20 \\
\hline $\mathbf{P}_{2} \mathbf{F}_{2}$ & 376.33 & 142.45 & 53.61 & 14.90 \\
\hline $\mathbf{P}_{2} \mathbf{F}_{3}$ & 414.80 & 160.79 & 66.45 & 18.47 \\
\hline$P_{3} F_{1}$ & 350.33 & 135.37 & 48.25 & 13.41 \\
\hline $\mathbf{P}_{3} \mathbf{F}_{2}$ & 384.33 & 144.51 & 55.60 & 15.46 \\
\hline $\mathbf{P}_{3} \mathbf{F}_{3}$ & 426.33 & 181.31 & 77.38 & 21.51 \\
\hline S.E. & 2.45 & 6.78 & 2.84 & 0.79 \\
\hline C.D. at 5\% & 7.18 & 20.29 & 8.49 & 2.37 \\
\hline
\end{tabular}

Interaction effect of pruning and fertilizer levels had also produced significant effect on reproductive parameters of guava fruits. The minimum days required for flowering (26.23),days required from flowering to fruit set (16.30), days required from fruit set to maturity (145.17) were observed in $45 \mathrm{~cm}$ pruning level with the application of $125 \%$ RDF (1000:500:500 g NPK/tree) $\left(\mathrm{P}_{3} \mathrm{~F}_{3}\right)$. The maximum values for fruit set $(80.33 \%)$ were also higher in $45 \mathrm{~cm}$ pruning level with application of 125\% RDF (1000:500:500 g NPK/tree) $\left(\mathrm{P}_{3} \mathrm{~F}_{3}\right)$ treatment.

The results of present table 3 revealed that, the yield parameters of guava were significantly influenced due to different pruning levels. Maximum number of fruits per tree $(389.00 /)$, weight of fruit $(153.73 \mathrm{~g})$, yield $(60.41 \mathrm{~kg} / \mathrm{ha}$.) and (16.79 t/ha.) was 
recorded in $45 \mathrm{~cm}$ pruning level $\left(\mathrm{P}_{3}\right)$. The minimum values were recorded in no pruning $\left(\mathrm{P}_{0}\right)$. Regarding to the fertilizer levels maximum number of fruits per tree (404.75), weight of fruit $(163.16 \mathrm{~g})$, yield $(66.19 \mathrm{~kg} / \mathrm{ha}$.) and (18.40t/ha.) was recorded in $125 \% \mathrm{RDF}$ (1000:500:500g NPK/tree) fertilizer application $\left(\mathrm{F}_{3}\right)$.

Interaction effect of pruning and fertilizer levels had significant effect on yield parameters. Maximum number of fruits per tree (426.33), weight of fruit (181.31g), yield $(77.38 \mathrm{~kg} / \mathrm{ha}$.) and $(21.51 \mathrm{t} / \mathrm{ha}$.) was recorded in $45 \mathrm{~cm}$ pruning level with the application of 125\% RDF (1000:500:500 g NPK/tree) $\left(\mathrm{P}_{3} \mathrm{~F}_{3}\right)$ treatment.

The results on yield of guava fruits revealed that, the increase in intensity of pruning level i.e. from light to severe viz. from $15 \mathrm{~cm}$, $30 \mathrm{~cm}$ to $45 \mathrm{~cm}$ level pruning increased the yield of guava fruits. Maximum pruning intensity (45 cm level pruning) produced maximum yield was obtained with appropriate fertilizer application to the plants (Abid et al., 2012). Increase in severity of pruning increases weight of fruit this is due to increase in number and area of leaves increases the amount of photosynthates cause a significant increase in size and weight of fruit.

These findings are well supported with the results of (Adhikari and Tandel, 2015) in guava. Increase in the size and weight of fruit is cause by drawing off photosynthates to the fruit as a consequence of intensification of the sink. (Bhuva et al., 2018) in pomegranate. Increase in weight of fruit could be due to utilization of whole food materials. Maximum yield was recorded in severe pruning it is due to more light interception within tree canopies as a result of pruning (Lakpathi et al., 2018) in guava. The pruning severity directly affected in increasing in average weight of fruit and yield of guava fruits. These findings are confirmed in (Rupankar et al., 2014).

Fertilizer application has best results on yield parameters of guava fruits by increase in weight of fruit, number of fruits also increase in dose of fertilizer increases the yield. This may due to higher dose of nitrogen, phosphorous and potash of nitrogen and phosphorous i.e. 125\% RDF (1000:500:500 g $\mathrm{NPK} /$ tree) increased weight of fruit (Abid et al., 2012) in phalsa. Improvement in yield parameters like number of fruits, weight of fruit may be due to increase in uptake of nutrients such as nitrogen (Baksh et al., 2008) in guava. The possible reason of increase in number of fruit and yield may be due to adequate supply of nutrient better growth and development of trees. The less in fertilizer application shows less in yield than higher fertilizer application levels this was simply due to availability of nutrients to those trees. (Dutta et al., 2018) in guava.

Interaction effect of pruning and fertilizer application has found significant in terms of weight of fruit, number of fruit and yield (Hiremath et al., 2017; Harishta et al., 2019) in guava. Significant increase in yield might be attributed to the increased fruit number per plant, fruit weight it is because of the NPK fertilization might accelerated the process of photosynthesis and it ultimately leads to increase in number of fruits and yield. Kaur and Kaur (2017) in guava. Fruit yield increased by better availability and uptake of nutrients by plant roots and enhancing the source-sink relationship by increasing the movement of carbohydrates from the leaves to fruits (Yadav et al., 2011).

In conclusion the pruning of tertiary branches of guava trees at $45 \mathrm{~cm}$ heading back of previous season growth with the application of fertilizer at 125\% of RDF@ 1000:500:500 $\mathrm{g} /$ tree produced beneficial effect on vegetative growth, flowering and yield of guava fruits. 


\section{References}

Abid M., Muzamil S., Kirmani S. N., Khan I. and Hassan A. 2012.Effect of different levels of nitrogen and severity of pruning on growth, yield and quality of phalsa (Grevia subinequalis L.).African J. of Agricultural Research. 7(35): 4905- 4910.

Adhikari Shiva and Tanka Prasad Kandel. 2015. Effect of time and level of pruning on vegetative growth, flowering, yield and quality of guava (Psidium guajava L.) International J. fruit science (15): 290-301

Baksh Hari, Yadav R. and Dwivedi R. 2008. Effect of INM on growth, yield, yield attributing characters and quality of guava (Psidium guajava L.) Cv. Sardar. Prog. Agric. Sci. 8 (2): 141-144.

Bhuva S.K., Chovatia R.S., and Baladha R.F. 2018.Standarization of severity of pruning and crop load on growth and yield in pomegranate (Punica granatum L.) var. Bhagwa. International J. of Chemical Studies, 6(6): 2900-2902.

Chaudhari Kalpana and Dhakare B.B. 2018. Influence of pruning intensities on growth, yield and fruit attributes of custard apple. Int. J. Curr. Microbiol. App. Sci. (7): 5311:5315.

Dahapute V.M., Joshi P.S., Tayade S.A. and Nagre P.K. 2018. Effect of severity of pruning on growth, yield and quality of custard apple International J. Chemical Studies., 6 (2):1606-1609.

DuttaPorismita, KotokyUtpal and Das Kaushik. 2018. Effect of integrated plant nutrient management of growth and yield of guava (Psidium guajava L.) cv. Allahbad Safeda. Bulletin Environment, Pharmacology and Life Sciences. 7 (11): 01-06.

Harrt, C.E 1969. Effect of potassium efficiency upon translocation of $14 \mathrm{C}$ in attached blades and entire plants of sugarcane. Plant physiol., 44: 1461 1469.

Hiremath Shewta, Athani S.I., Pujar D.U., Choudhary P.R., and Allolli T.B. 2017. Role of pruning and bioregulators in reproductive and yield attributes of guava (Psidium guajava L.) Var. Sardar. International J. Pure and Applied Bioscience. 5(3): 703-708.

Kumar and Rattanpal 2010. Effect of pruning in guava planted at different spacings under Punjab conditions. Indian J. Hort.67 Special issue, Pp. 115-119.

Kaur Harpinder and KaurGurpinder 2017. Effect of inorganic and organic fertilizers on fruit quality and yield attributes in guava cv. Sardar. Int. J. of Advanced Research., 5(12): 1346-1351.

Lakpathi Guguloth and Matta Rajkumar 2018. Effect of pruning intensities and fruit load on yield and quality of guava under high density planting system. Int. J. Cutt. Microbio. App. Sci., 7(5): 18531860.

LianHauNgiah, Singh B., Senjam B.D. and Ramjan Md., 2019.Effect of shoot pruning on growth and yield of guava (Psidium guajava L.) cv. L-49 under Foothills of Arunachal Pradesh. Int. J. Curr. Microbiol. App. Sci. 8(3):20202027.

Rupankar B., Bhagwati K. and Choudhary V. K. 2015. Effect of pruning intensities on the performance of fruit plants under Mid- Hill condition of Eastern Himalays : case study on guava. International Letters of Natural Sciences 46: 46-51.

Sawant N.S., Kalam S.R. and Naglot U.M. 2018.Effect of levels of pruning on growth parameters of guava Var. Sardar. International Journal of Chemical Studies 6(5): 2720-2722.

Shukla A.K., Sarolia D.K., Bhavana K., Kaushik R.A., Mahawer L.N. and Bairaw H.L. 2009. Evaluation of substrate dynamics for integrated 
nutrients management under high density planting of guava cv. Sardar. Indian J. Hort.66(4):461-464

Yadav P.K., Yadav A.L., Yadav A.S., Yadav H.C. and Singh Y.P. 2011. Effect of integrated nutrient nourishment on yield attributes and economics of papaya (Carica papaya L.) fruit cv. Pusa Dwarf. Plant Archives 2011b; 11(1): 307-309.

\section{How to cite this article:}

Shinde, S. B., B. M. Kalalbandi, P. A. Kate and Shriram, J. M. 2020. Effect of Pruning Regimes and Fertilizer Levels on Growth, Flowering and Yield of Guava (Psidium guajava L.). Int.J.Curr.Microbiol.App.Sci. 9(11): 3467-3475. doi: https://doi.org/10.20546/ijcmas.2020.911.413 